\title{
Towards truth in advertising in US university education
}

\section{Washington}

William J. Bennett, Secretary of Education in the Reagan Administration for the past two years, is a name with which to inflame academics. Bennett's pitch is that the quality of higher education in the United States is deficient because academics neglect their primary responsibility (to teach) and that universities are bilking the US economy by increasing tuition fees unjustifiably. But he says that the New York Times, not he, was responsible for the word "greed" in the headline above a statement of his case last week.

Contrary to academic suspicion, Bennett does not have horns growing out of his head. His special unpopularity on the campuses of the United States may stem from his own academic background Williams College, a $\mathrm{PhD}$ in philosophy at Austin, Texas, a law diploma at Harvard Law School and some years of teaching and administration at Boston University, President John Silber's centre of successfully self-proclaimed excellence; apostates are rarely loved. In 1981, Bennett was President Reagan's first appointment as chairman of the National Endowment for

\section{New Indo - Soviet}

\section{space agreement}

\section{Bangalore}

As part of an agreement between the Soviet Union and India to improve telecommunications between the two countries, the Soviet posts and telecommunications ministry will give technical help in setting up an Intersputnik Earth station in India. India is also likely to lease transponders on a Soviet communications satellite, which will make possible an exchange of television and radio broadcasts.

During the visit of the Soviet leader, $\mathrm{Mr}$ Mikhail Gorbachev, to India at the end of last year, the Soviet delegation suggested the establishment of a space centre in India to train cosmonauts from developing countries.

India has also concluded an agreement with the Soviet agency Glavcosmos for the launching this year of India's three-axisstabilized operational Earth observation spacecraft, IRS, from the Soviet Union. India is said to be the first ever customer to hire the launch service offered by Glavcosmos and this will be the first commercial launch of an Indian spacecraft from the Soviet Union. India's first satellite, Aryabhata, and the experimental Earth observation spacecraft in the Bhaskara series were put into space free of charge by the Soviet Intercosmos vehicle.

Radhakrishna Rao

\author{
the Humanities.
}

Bennett makes no bones about his objectives: "I'm deliberately setting out to improve the quality of higher education", but quality is carefully defined. Bennett says the essence of his complaint is that universities are failing to deliver what they promise. He says there is a huge gap between the rhetoric of university catalogues ("we collect them here") and the actual experiences of undergraduates. He cites as evidence the Boyers report from the Carnegie Commission for Higher Education last November, with its account of the incidence of student dropouts and of discontent among those who stay.

If colleges accurately advertised their wares, one gathers, the secretary would be content, knowing that institutions offering second-quality goods would then not find students. In the marketplace for higher education, Bennett is the campaigner for better advertising standards. "To thine own claims be true" is his motto.

But are not many institutions providing an excellent education? Bennett says his complaints apply to "most places", not to all. Faced with the example of one university given a glowing report card by an external invigilating group, Bennett quickly says "I'll take some credit for that". After two years of demanding systematic evaluation of universities, "I think we've won that argument"

On research, Bennett deplores the ease with which universities can upgrade their status, duplicating each other's efforts and increasing the demands on federal funds for research grants. "North Carolina used to have two universities, now it has seventeen", he says, offering as an illustration of the research contagion the way in which state system colleges give themselves airs above what used to be their station.

Bennett is offended by the "higher education lobby, which has done a very good job", and almost sympathetic to the US Congress, "which has to face it year after year". "If you want to use the word greedy", the lobbying on behalf of universities during the debate over last year's Tax Reform Act is where it applies, he says.

In the event, the private universities represented by the American Council on Education appear to have lost most of their claims for tax exemption for charitable gifts and the capital appreciation of property, while not all scholarships and fellowships will in future be tax-exempt.

In reality, Bennett says, it is "balderdash" for the universities to act poormouth when higher education has an aggregate income of more than $\$ 100,000$ million a year. His constant theme is that there would be plenty of money for the universities if only it were wisely spent.

Bennett's draft budget for the financial year beginning next October would make the federal government, which even now contributes only $6-7.5$ per cent of the total, an even smaller player. The administration hopes it will be allowed to save $\$ 5,500$ million from educational programmes, but the Secretary of Education seems less than confident that Congress will allow him to spend so little.

There will be a bitter argument over financial support for university students. Bennett makes no bones of his objectives; access for young people likely to benefit from higher education, but not at the expense of "taxpayers who never go to university". He declares that there cannot be

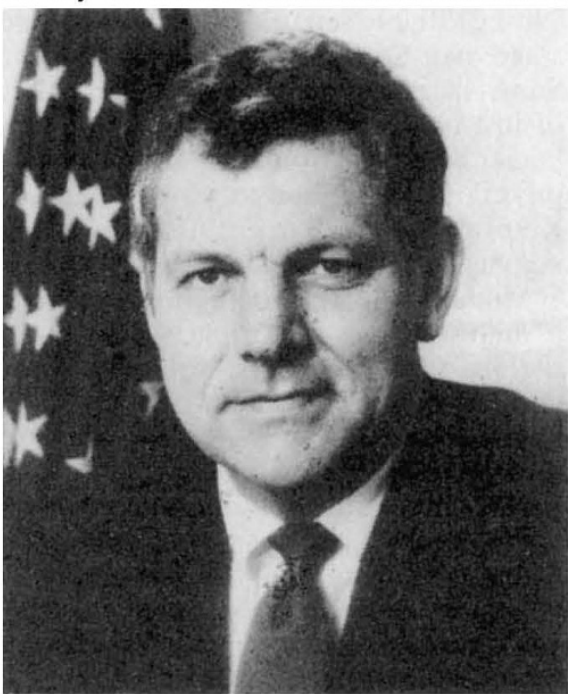

William J. Bennett - inconoclast or populist? much wrong with a system in which 60 per cent of young people at least begin on higher education courses of some kind, but insists that, in equity, the burden of student support should be shifted from the present system of modest grants and interest-subsidized loans to one in which interest would not be subsidized but the rate of loan repayment determined by a graduate's salary.

Bennett will not be discomfited by the budget battle ahead. Down-to-earth though he may be, there is a touch of the messianic about him, as if he has a vision of how the universities of the United States could prosper in a free market for higher education. If unsurprised that most academics do not share his vision, he talks as if it is only a matter of time before they are converted. He has one powerful influence on his side - the knowledge that in the climate of disappointment that marks the beginning of the next presidential election campaign, the charge that the universities of the United States have shortchanged their clients may strike a popular chord. But Bennett has a soft spot for the problems of research in the humanities, including Greek and Latin, which may yet win him unexpected friends. John Maddox 